\title{
Prevalence of mammary alterations in women assisted in a municipality in the state of Paraná
}

\author{
Prevalência de alterações mamárias em mulheres \\ atendidas em um município do estado do Paraná \\ Prevalencia de alteraciones de mama en las mujeres \\ atendidas en una ciudad del estado de Paraná
}

\author{
Samara Ronchi ${ }^{\mathrm{a}}$ \\ Lediana Dalla Costab \\ Alessandro Rodrigues Perondic \\ DurcelinaSchiavoni Bortoloti ${ }^{\mathrm{d}}$ \\ Evellyn Claudia Wietzikoski
}

D0l: $\quad$ http://dx.doi.org/10.1590/19831447.2014.02.43580

\footnotetext{
Nurse, graduated from Universidade Paranaense (UNIPAR), Francisco Beltrão, Paraná, Brazil.

${ }^{b}$ Masters in Occupational Management and Healthcare, Coordinator of the Nursing Graduate course at UNIPAR, Francisco Beltrão, Paraná, Brazil.

Masters in Occupational Management and Healthcare, Professor for the Nursing Graduate course at UNIPAR, Francisco Beltrão, Paraná, Brazil.

${ }^{d}$ Working on a PhD in Health Sciences from the Universidade Estadual de Londrina (UEL), Professor for the Physical Education Graduate course at UNIPAR Francisco Beltrão, Paraná, Brazil.

e PhD in Pharmacology, Executive Director of Research and Post-Graduate Management at UNIPAR Umuarama, Paraná, Brazil.
}

\section{ABSTRACT}

The purpose of this quantitative and retrospective study was to analyze the prevalence of mammary alterations from 1304 women in the city of Francisco Beltrão - Paraná (PR), Brazil, registered in theSISMAMA system, froma Regional Health Center in Paraná State. Between 2009 and 2012, data was collected in May and June 2013 and statistically analyzed. The results showed that 694 (53.2\%) of women were under 49 years old, 1126 (86.3\%) had no increased risk for developing breast cancer, and 1205 (92.5\%) underwentmammography screening. Color and tracking information were omitted in most entries. The BI-RADS ${ }^{\circledR}$ category 0 (inconclusive result) was the most prominent. Categories with higher chances of malignancy (BI-RADS ${ }^{\circledR} 4$ and 5) prevailed in the left breast in women older than 50. Diagnosis of radial sclerosing lesions associated with infiltrating ductal carcinoma was predominant in 53.0\% $(n=9)$ of the histopathological exams. We conclude that these findings are partially supported by the literature.

Descriptors: Breast diseases. Women. Mammography. Epidemiology.

\section{RESUMO}

Este estudo quantitativo e retrospectivo teve como objetivo analisar a prevalência de alterações mamárias de 1304 mulheres do município de Francisco Beltrão - Paraná (PR), Brasil, cadastradas no SISMAMA de uma Regional de Saúde do Estado do Paraná, entre 2009 e 2012. Os dados foram coletados em maio e junho de 2013 e analisados estatisticamente. Os resultados apontaram que 694 (53,2\%) mulheres tinham idade até 49 anos, 1126 (86,3\%) não possuíam risco aumentado para desenvolver câncer de mama, 1205 (92,5\%) realizaram mamografia de rastreamento. Cor e seguimento foram informações omitidas na maioria dos cadastros. Predominou a categoria (BI-RADS ${ }^{\circledR}$ 0) exame inconclusivo). Categorias com maiores chances de malignidade (BI-RADS ${ }^{\circledR} 4$ e 5) prevaleceram na mama esquerda de mulheres acima de 50 anos. Diagnóstico de lesão esclerosante radial associada ao carcinoma ductalinfiltrante predominou em 53,0\% ( $n=9)$ dos exames histopatológicos. Conclui-se que estes dados são parcialmente corroborados pela literatura. Descritores: Doenças mamárias. Mulheres. Mamografia. Epidemiologia.

\section{RESUMEN}

Este estudio cuantitativo y retrospectivo tuvo como objetivo analizar la prevalencia de las alteraciones mamarias en 1.304 mujeres del municipio de Francisco Beltrão- Paraná (PR), Brasil, inscrito en el SISMAMA de la Regional de Salud del Estado de Paraná, entre 2009 y 2012, los datos fueron recolectados en mayo y junio de 2013 y se analizaron estadísticamente. Los resultados mostraron que 694 (53,2\%) mujeres tenían hasta 49 años 1126 (86,3\%) no tenían mayor riesgo para el cáncer de mama, 1205 (92,5\%) fueron sometidos a la mamografía de rastreo. La información de color y el seguimiento se omite en la mayoría de las entradas. Predominan la categoría BI-RADS ${ }^{\circledR} 0$ (examen inconcluyente). Categorías con mayores posibilidades de malignidad (BI-RADS ${ }^{\circledR} 4$ y 5 ) fueron superiores para el seno izquierdo en mujeres mayores de 50 años. Diagnóstico de las lesiones esclerosantes radiales asociados con carcinoma ductal infiltrante fue predominante en 53,0\% ( $n=9)$ de la histopatología. Llegamos a la conclusión de que estos resultados son parcialmente compatibles con la literatura.

Descriptores: Enfermedades de la mama. Mujeres. Mamografía. Epidemiología. 


\section{口INTRODUCTION}

Breast cancer is the cancer developed most by females and the leading cause of death of women in Brazil. An estimate published by the National Cancer Institute predicts an incidence of 57,120 new cases of breast cancer for 2014 ${ }^{(1)}$.

In some developed countries, although there is an increase in the prevalence of breast cancer, there is a reduced mortality rate, which is associated with early detection, through screening mammography and proper treatment. In Brazil, the increased incidence has been accompanied by an increase in mortality, attributed to late diagnosis and treatment ${ }^{(2)}$. The prognosis for breast cancer is good, if it is diagnosed in the initial stages.

Given thissituation, controlling breast cancer is characterized as a priority in Brazil's public healthcare policy. Therefore, the Ministry of Health instituted, in 2008, the Breast Cancer Information System(Sistema de Informação do Câncer de Mama) (SISMAMA), a subsystem of the Unified Health System, whose objective is to monitor and manage actions for early detection and register mammograms with alterations, allowing for follow-up ${ }^{(2)}$. This registry is also important for good management and directing resources to regions where there are higher rates of breast cancer.

However, a significant gap in previous studies has led to a lack of investigation related to the information contained in the SISMAMA registries. In this context, the highest number of reports related to the risk factors and record for follow-up are necessary, since the study reports that improper follow-up in North American cities has been associated with a high prevalence and mortality rate for breast cancer ${ }^{(3)}$.

The mammary alterations registered in the SISMAMA are based on categorization of the Breast/magingReportingand Data System (BI-RADS $\left.{ }^{\circledR}\right)$, published by the American College of Radiology (2003) and brought to Brazil by the Brazilian College of Radiology. This system standardizes the mammogram report and suggests clinical procedures in accordance with the findings of the mammographic exams ${ }^{(2)}$.

According to the fourth edition of the BI-RADS ${ }^{\circledR}$, the exams are classified based on the index of clinical suspicion of the lesions: category 1 (none found), category 2 (only benign found), category 3 (most-likely benign found), category 4 (findings that are most-likely malignant), category 5 (findings highly suspicious for malignancy). Lesions that need additional assessment using an ultrasound scan are classified in category 0 , and those that have a previously confirmed histopathological diagnosis of malignant are classified in category $6^{(2)}$.
For the success of these acts (reduction of 20 to $30 \%$ of the mortality rate for breast cancer) it is fundamental that the program reaches a significant percentage of the female population, through quality scanning exams and diagnoses, with guaranteed access to treatment ${ }^{(4)}$. Given that, currently, studies in Paraná are reporting that $58.4 \%$ of women older than 60 have breast cancer ${ }^{(5)}$ and estimate that there will be 10,370 new cases for 2014 in women who live in the southern region of Brazil.

The southern region stands out for its high rate of breast cancer, with higher numbers than the northern and mid-western regions ${ }^{(5)}$. The southeastern region of Paraná is a region that is in great need of epidemiological studies about this pathology, since research has been directed toward the state's larger cities, to the detriment of small and medium-sized towns such asFrancisco Beltrão, which has been a part of the SISMAMA since 2009.

Therefore, this study, which resulted in a dissertation for the Graduate Nursing Course at the Universidade Paranaense (UNIPAR) $)^{(6)}$, aimed to analyze the prevalence of mammary alterations for women registered in the SISMAMA of the Eighth Regional Health Center of the State of Paraná ( $8^{\text {th }} \mathrm{RS}$ ), which is in the town of Francisco Beltrão (PR), Brazil, from 2009 to 2012.

\section{METHODS}

This study, which took a quantitative and retrospective documental approach, used public files from the SISMAMA, supplied by the $8^{\text {th }} R S$, which serves 27 municipalities and a population of approximately 337,750 inhabitants. The focus of the study was the town of Francisco Beltrão, home of the $8^{\text {th }} \mathrm{RS}$.

The project, which was analyzed by the Research Ethics Committee of UNIPAR, in accordance with resolution 196/96 of the National Health Council, was approved under protocol 335.506. After training received by the employees of the $8^{\text {th }}$ RS, in May and June, 2013, the researchers collected and analyzed data from 1304 records from the SISMAMA, of women living in the town of Francisco Beltrão, from 2009 to 2012. For the data collection, the data contained in the SISMAMA was recorded on an Excel $^{\circledR}$ spreadsheet.

The period that the research refers to is from the time that the program was implemented (2009), after being instituted in December 2008, until December 2012, taking into account that the project was concluded in the first half of 2013. It is a project noting that the data contained in the SISMAMA came from information taken from the basic healthcare network, from the services and mammograms done on women in the town of Francisco Beltrão. There- 
fore, all the women registered in SISMAMA, within the designated period, were included in the study. The male records were excluded.

The information analyzed included: age, ethnicity, year the exam was performed, clinical indication of the mammogram, BI-RADS ${ }^{\circledR}$ categorization of the right and left breast, additional exams (cytopathological and histopathological), follow-up status and presence of increased risk for developing breast cancer (CAM) (information present in the mammogram request form related to family history for CAM with first degree kinship and personal history of mammary lesions).

For treatment of the data, descriptive statistics, with an analysis of frequency for categorized data, were used, in order to determine prevalence. For possible associations between increased risk for CAM and age, the chi-square test $\left(X^{2}\right)$ was used and the significance adopted was $p<0.05$.
The analyses were developed using the IBM StatisticalPackage for the Social Scienceversion 17.0 software (Windows; (hicago, IL, USA).

\section{RESULTS}

In the 1304 records identified during the research, a predominance of Caucasian woman, under 49 years of age (average $49.7 \pm 9.8$, a data not shown in the table) was found for data not reported in the majority of the records (Table 1).

There were no significant associations identified between age and increased risk for CAM $(p=0,791)$ (Table 2). However, we verified that the prevalence of women that had an increased risk was small when compared to those who did not have said risk. When we looked at the ages, we identified a risk prevalence that was closely related, both

Table 1. General characteristics of women registered in the SISMAMA, who live in the town of Francisco Beltrão (PR), Brazil, 2009-2012.

\section{Characteristics}

$\mathbf{N}$

$\%$

Age $(n=1304)$

49 years and younger

694

53.2

Over 50 years old

610

46.8

Total

1304

$100 \%$

Ethnicity $(n=1304)$

$\begin{array}{lcc}\text { Caucasian } & 75 & 5.7 \\ \text { Biracial } & 02 & 0.2 \\ \text { Not given } & 1227 & 94.1 \\ \text { Total } & 1304 & 100 \%\end{array}$

Source: SISMAMA

Table 2. Association between increased risk for developing CAM and age of women registered in the SISMAMA, living in the town of Francisco Beltrão (PR), Brazil, 2009-2012.

\begin{tabular}{lcccccc} 
& \multicolumn{2}{c}{ Under } & $\mathbf{4 9}$ years old & \multicolumn{2}{c}{$\mathbf{5 0}$ years or older } & \multicolumn{2}{c}{ Total } \\
Risk & $\mathbf{N}$ & $\mathbf{\%}$ & $\mathbf{N}$ & $\mathbf{\%}$ & $\mathbf{N}$ & $\mathbf{\%}$ \\
\hline Yes & 57 & 8.2 & 43 & 7.0 & 100 & 7.7 \\
No & 594 & 85.6 & 532 & 87.2 & 1126 & 86.3 \\
Unknown & 16 & 2.3 & 15 & 2.5 & 31 & 2.4 \\
No info. & 27 & 3.9 & 20 & 3.3 & 47 & 3.6 \\
Total & 694 & 53.2 & 610 & 46.8 & 1304 & $100 \%$ \\
\hline
\end{tabular}

Source: SISMAMA.

Chi-square (risk and age): $p=0.791$ 
for the younger and older women. Similar data was confirmed for women that did not present risk.

With regards to the distribution of frequency of exams, there was a high prevalence of screening mammograms $(92.5 \%, n=1205)$, followed by the diagnostic mammograms $(6.3 \% ; n=82)$ and histopathological exams $(92.5 \%, n=1205)$, followed by diagnostic mammograms $(6.3 \% ; n=82)$ and histopathological exams (1.3\%; $n=17)$. There were no records of cytopathological exams during the period studied.

The distribution of scanning and diagnostic exams registered per year, in the town of Francisco Beltrão is presented in Table 3. The year in which the most registrations occurred was in 2010, prevailing screening mammogram every year. However, despite the diagnostic mammograms that were done during the entire period analyzed, there were more performed in 2009. Yet the histopathological exams were recorded only in 2011 and 2012.

The BI-RADS ${ }^{\circledR} 0$ classification (inconclusive exam) prevailed in the right and left breasts for women under 49 and over 50. Category 1 prevailed in the left breast for younger women. Categories 2, 3, 4 and 5 prevailed in the left breast of women over 50 (Table 4). There were no records found for women who were in BI-RADS ${ }^{\circledR}$ category 6.

The results of the histopathological exam show a predominance of radial sclerosing lesions associated with infiltrating ductal carcinoma (Table 5).

With regards to the follow-up status, $27.8 \%(n=363)$ of women were being monitored during the time period. Only $0.2 \%$ ( $n=03$ ) of them completed follow-up and $0.2 \%$ $(n=03)$ were not found. There were no records of refusal/ abandonment of follow-up, however, in $71 \%(n=935)$ of the registrations, this item was not reported.

\section{DISCUSSION}

The principal findings of this study were the reports of the rates of prevalence of mammary alterations on different variables listed in the SISMAMA of the $8^{\text {th }} \mathrm{RS}$, in the town of Francisco Beltrão (PR), Brazil, an important town in the southeastern region of Paraná, and the main omissions of information verified in the system. It is worth noting that this region is also in great need of epidemiological studies

Table 3. Distribution of frequency of exams for scanning and diagnoses of mammary alterations recorded per year in the SISMAMA, in the town of Francisco Beltrão (PR), Brazil, 2009-2012.

\begin{tabular}{lcc} 
Exams/Year & N (1304) & \% \\
$2009(n=242)$ & 208 & 86.0 \\
$M R$ & 34 & 14.0 \\
$M D$ & 242 & $100 \%$ \\
Total & & \\
\hline $2010(n=429)$ & 414 & 96.5 \\
$M R$ & 15 & 3.5 \\
$M D$ & 429 & $100 \%$ \\
Total & & \\
\hline $2011(n=357)$ & 341 & 95.5 \\
$M R$ & 11 & 3.1 \\
$M D$ & 5 & 1.4 \\
EH & 357 & $100 \%$ \\
Total & & \\
\hline $2012(n=276)$ & 242 & 87.7 \\
$M R$ & 22 & 8.0 \\
$M D$ & 12 & 4.3 \\
EH & 276 & $100 \%$ \\
Total & & \\
\hline & &
\end{tabular}

Source: SISMAMA

$M R=S c r e e n i n g M a m m o g r a m ; M D=$ Diagnostic Mammogram; EH = Histopathological Exams. 
Table 4. Distribution of frequency of BI-RADS ${ }^{\oplus}$ categories per age in the right and left breasts of women registered in the SISMAMA, in the town of Francisco Beltrão (PR), Brazil, 2009-2012.

\begin{tabular}{lcccc} 
& \multicolumn{2}{c}{ Right Breast } & \multicolumn{2}{c}{ Left Breast } \\
\hline \multicolumn{1}{c}{ Variable } & N & \% & N \\
Under 49 (n= 694) & & & 322 & 46.4 \\
\hline Category 0 & 323 & 46.5 & 216 & 31.1 \\
Category 1 & 215 & 31.0 & 96 & 13.9 \\
Category 2 & 98 & 14.1 & 46 & 6.6 \\
Category 3 & 39 & 5.7 & 07 & 1.0 \\
Category 4 & 10 & 1.4 & 00 & 0.0 \\
Category 5 & 01 & 0.1 & 07 & 1.0 \\
Not Reported & 08 & 1.2 & 694 & $100 \%$ \\
Total & 694 & $100 \%$ & & 39.6 \\
\hline Over 50 (n= 610) & & & 242 & 22.0 \\
\hline Category0 & 257 & 42.1 & 134 & 24.4 \\
Category 1 & 124 & 20.3 & 149 & 8.2 \\
Category 2 & 153 & 25.1 & 50 & 2.3 \\
Category 3 & 53 & 8.7 & 14 & 0.7 \\
Category 4 & 09 & 1.5 & 04 & 2.8 \\
Category 5 & 01 & 0.2 & 17 & $100 \%$ \\
Not Reported & 13 & 2.1 & 610 & \\
Total & 610 & $100 \%$ & & \\
\hline
\end{tabular}

Source: SISMAMA

Table 5. Distribution of types of lesions found during the histopathological exam for women registered in the SISMAMA, in the town of Francisco Beltrão (PR), Brazil, 2009-2012.

\begin{tabular}{|c|c|c|c|c|c|c|}
\hline \multirow[b]{2}{*}{ Type of lesion } & \multicolumn{2}{|c|}{ Right Breast } & \multicolumn{2}{|c|}{ Left Breast } & \multicolumn{2}{|c|}{ Total } \\
\hline & $\mathbf{N}$ & $\%$ & $\mathbf{N}$ & $\%$ & $\mathbf{N}$ & $\%$ \\
\hline CDI & 03 & 17.5 & 00 & 0.0 & 03 & 17.6 \\
\hline LER & 00 & 0.0 & 01 & 5.8 & 01 & 5.9 \\
\hline $\mathrm{LER}+\mathrm{CDI}$ & 05 & 29.4 & 04 & 23.5 & 09 & 53.0 \\
\hline $\mathrm{HDA}+\mathrm{CDI}$ & 01 & 5.8 & 02 & 11.7 & 03 & 17.6 \\
\hline $\mathrm{HDA}+\mathrm{CLI}$ & 01 & 5.8 & 00 & 0.0 & 01 & 5.9 \\
\hline Total & 10 & 58.9 & 07 & 41.1 & 17 & $100 \%$ \\
\hline
\end{tabular}

Source: SISMAMA

$C D \mid=$ Invasive ductal carcinoma; $\mathrm{LER}=$ Radial sclerosing lesion; HDA= Atypical ductal hyperplasia; $C L \mathrm{~L}=$ Invasive lobular carcinoma.

about breast cancer. Therefore, the results of this study will contribute to remedying the difficulties regarding the inclusion of information necessary for the system to operate properly and for increasing the awareness of the profes- sions that supply it, as well as assist in guiding the public policies and resources for the region.

The study was done on the SISMAMA of the $8^{\text {th }}$ RS, using records of women who live in the town of Francisco Beltrão 
(PR), Brazil, which as 78,943 inhabitants, of which 39, 985 are female $\mathrm{e}^{(7)}$. The town is where the $8^{\text {th }} \mathrm{RS}$ is located and the center for medical care for the southeastern region.

The age range found in the retrospective transversal study, which analyzed 2,481 registrations of women in the SISMAMA of the town of Santa Cruz do Sul - Rio Grande do Sul (RS), Brazil, in 2010, was from 50 to 69 years old (59.6\%) (8), the age range recommended by the Ministry of Health for performing screening mammograms, different from this study where the women were, predominantly, under 49 53.2\%). As for ethnicity, part of this sample is Caucasian (5.7\%). However, for the majority of the records, this information was omitted (94.1\%). In other studies these omission indices are not as significant $(64.6 \% \text { and } 30.5 \%)^{(8-9)}$.

The goals of the SISMAMA, in addition to monitoring patients with altered mammograms, seek to create a base for detection and opportune screening for breast cancer from reports of data generated by this screening and detection. Therefore, the full completion of the fields available in the system, by the unit that receives the women and by the laboratory that performs the exam, is of fundamental importance, since this data subsidizes the monitoring and management of early detection of breast cancer and the formulation of Public Policies to reduce the morbidity and mortality rates of this illness in Brazil.

In the sample there was a prevalence of women who did not have an elevated risk for developing breast cancer (86.3\%), similar to the study that analyzed data from women that had mammograms in the city of Santa Cruz do Sul $(\mathrm{RS})^{(8)}$, Brazil. Presenting an elevated risk for developing breast cancer means that the woman has a family history of at least one person who is a first degree relative with a diagnosis of female breast cancer before the age of 50 , bilateral breast cancer or ovarian cancer at any age, male and female breast cancer, or even women with a previous histopathological diagnosis of an atypical proliferative breast lesion or lobular neoplasia in situ(10).

The fact that most participants did not have an increased risk for developing breast cancer is in accordance with what is expected from a screening program, which looks for, among the population, women who are asymptomatic and not at risk, seeking early diagnosis and treatment.

The most effective forms of early detection of mammary alterations are a clinical breast exam, performed by a healthcare professional, and a mammogram. Whereas cytopathological or histopathological biopsies are done in cases of suspected malignancy of findings from the mammogram ${ }^{(4)}$.

In the period studied, the screening mammogram was the exam that was performed the most (92.5\%). A recentralized ecological study in the city of Goiânia (GO), Brazil, analyzed data reported in the SISMAMA of 31,454 mammograms done through SUS and identified a prevalence of screening mammograms similar to this study ${ }^{(11)}$. Meta-analysis studies showed that around $30 \%$ of the mortality rate for breast cancer in women over 50, reduced with the implementation and realization of screening mammograms, due to early detection ${ }^{(12)}$.

Exams done for screening and diagnosing mammary alterations in the sample prevailed in 2010 (32.9\%), decreasing $11.7 \%$ by 2012 . This is different from national data, where, within the first half of 2010, around 1.6 million mammograms were performed, climbing to 2.1 million in 2012, a 28\% increase. In the state of Paraná, 69,885 mammograms were done in the first half of 2010 and 80,304 in the first half of 2012, on women between 50 and 60 years of age, indicating a $14.9 \%$ increase in the number of mammograms performed ${ }^{(13)}$.

The reduced percentage of mammograms done in the town of Francisco Beltrão may be related to the wait time for having the exam, leading to absenteeism, a problem also faced in other towns in the region, and a reduction in financial resources available for this purpose. Another factor that possibly may compromise this data is the low number of records of the results and follow-up of mammograms, decreasing the percentage when compared to the national and state data.

Classification of the results of mammograms in the SISMAMA is based on the BI-RADS ${ }^{\circledR}$ categorization, which seeks to simplify the results and estimate predictive values (probability of malignancy) of the findings in the exam, in addition to recommending clinical procedures for each category ${ }^{(2)}$. In the study, the BI-RADS ${ }^{\oplus}$ category 0 (inconclusive exam) was the most prevalent (43.8\%). On the other hand, the transversal study that analyzed mammogram requests for 7,982 women in a public service for the state of Acre, Brazil, between 2004 and 2008, identified a prevalence of $41.1 \%$ for category $1^{(14)}$, the same the occurred in an ecological study done in Goiânia (GO), Brazil, where the prevalence of BI-RADS $^{\oplus} 1$ was $55.8 \%{ }^{(11)}$.

Categories 4 and 5 of the BI-RADS ${ }^{\circledR}$ classification, which refer to suspicious and highly suspicious lesions, were the least prevalent in this study, but the most relevant because they are precursor lesions of breast cancer, these prevailed in the left breast of women over 50, despite the lack of significant association between risk and age in this study. Similar results were reported in the state of Acre, Brazi ${ }^{(14)}$. A study done with 2,930 records of women who received treatment for breast cancer at the Santa Rita de Cássia Hospital, in Vitória (ES), between 200 and 2006, found a prevalence of $49.6 \%$ of lesions present in the left breast ${ }^{(15)}$. 
The SISMAMA stores data from mammogram exams, records information about cytopathological and histopathological exams and their results, and also recommends actions for each category. Cytopathological exams were registered in the period studied, while the histopathological exams were registered in 1.3\% of the participants. These are exams recommended in cases of suspicious and highly suspicious alterations.

As for the results of the histopathological exams, there was a prevalence of a radial sclerosing legion associated with invasive ductal carcinoma (53.0\%) (association of benign and malignant lesions). In a retrospective transversal study that analyzed 278 medical records of women that had the histopathological exam using the "core biopsy" method, in the city of Cuiabá (MT), Brazil, in 2009, a prevalence of $77 \%$ benign diagnosis was found ${ }^{(16)}$, different from the present study.

In addition to the aforementioned actions and objectives, the SISMAMA program seeks to monitor women who have had altered exams, by performing a follow-up. In the sample studied, there was a prevalence of the absence of information regarding follow-up (71.8\%). The absence of information or non-completion of fields in the system generates a burden and sub-information for the SISMAMA.

\section{CONCLUSION}

The results of this study indicate that the majority of women from Francisco Beltrão registered in the SISMAMA from the $8^{\text {th }}$ RS of the state of Paraná, between 2009 and 2012, were less than 49 years old, and did not have an increased risk for developing CAM and had a screening mammogram, with a predominance of the BI-RADS ${ }^{\oplus}$ category 0. Categories with greater chances of malignancy prevailed in the left breast of women over 50 . The diagnosis of a radial sclerosing lesion associated with invasive ductal carcinoma was predominant in the histopathological exams. There was also a prevalence of significant indices of omissions of information for the ethnicity and follow-up variables.

Nevertheless, despite the present investigation having produced information that is important, from a research perspective, for women's health in a town in the southeast of Paraná, some limitations may not be disregarded. The lack of information contained in the system limited the most reliable results with relation to some variables studied. In addition, the lack of surveying data in the other towns that are part of the $8^{\text {th }}$ RS hinders the expansion of the results for the region as a whole.

However, the data found is partially corroborated by the literature from the field of study, but strategies are needed for increasing the effectiveness of the system, principally with relation to the indices of omissions and sub-information contained in the research.

Therefore, it is worth pointing out that this study may contribute to the training of future nursing professionals, in view of the importance of the nurse professional in implementing the SISMAMA, managing preventative actions, identifying the population that is most vulnerable to CAM, leading to screening, diagnostic proof and treatment. The information generated in the towns and managed by the nurses is sent to the Regional Health Centers, State Health Departments and the Ministry of Health, and pooled to generate national data reports that are the basis for Controlling Cancer and Public Policies.

Lastly, so that strategies such as the SISMAMA produce effective results, greater engagement from the healthcare team and managers that provide care for these women is needed, as well as acting with commitment and responsibility, from proper and early screening, to timely treatment or procedures for each situation.

\section{DEFERENCES}

1. Ministério da Saúde(BR),Instituto Nacional do Câncer. Estimativa 2014: incidência de câncer no Brasil [Internet]. Brasília (DF): Instituto Nacional do Câncer; 2014 [citado2014 fev12]. Available in: www.inca.gov.br/estimativa/2014.

2. Ministério da Saúde(BR), Instituto Nacional do Câncer. Sismama: informação para 0 avanço das ações de controle do câncer de mama no Brasil. Rio de Janeiro;2010.

3. Brooks SE, Hembree TM, Shelton BJ, Beache SC, Aschbacher G, Schervish PH, et al. Mobile mammography in underserved populations: analysis of 3,923 woman. J Community Health. 2013;38(5):900-6.

4. Ministério da Saúde (Brasil), Agência Nacional de Saúde Suplementar. Manual técnico para promoção da saúde e prevenção de riscos e doenças na saúde suplementar. Rio de Janeiro; 2011.

5. Melo WA, Souza LA0, Zurita RCM, Carvalho MDB. Fatores associados na mortalidade por câncer de mama no noroeste paranaense. Revista Eletrônica Gestão e Saúde. 2013;(nesp):2087-94.

6. Ronchi, S. Prevalência de alterações mamárias em mulheres atendidas em um município da Oitava Regional de Saúde do estado do Paraná [monografia]. Francisco Beltrão (PR): Universidade Paranaense (UNIPAR); 2013.

7. Instituto Brasileiro de Geografia e Estatística. Censo Demográfico 2010 [Internet]. Rio de Janeiro; 2010 [citado 2013 set 07]. Available in:http://www.ibge. gov.br/cidadesat/xtras/perfil.php?codmun $=410840 \&$ search $=$ parana|francis co-beltrao.

8. Martins AFS, Nogueira G, Santos IP, Borges DT. Determinação do perfil das pacientes que realizam mamografia em Santa Cruz do Sul - RS a partir do sistema de informação do controle do câncer de mama (SISMAMA) [Internet]. In: Anais do III Salão de Ensino e Extensão Vivenciando a Integração; 2012. Santa Cruz do Sul: Universidade de Santa Cruz do Sul; 2012 [citado 2013 set 07]. Available in: http://online.unisc.br/acadnet/anais/index.php/salao_ensino_extensao/ article/view/10511. 
9. Santos SBL, Koch HA. Análise do sistema de informação do programa de controle do câncer de mama (SISMAMA) mediante avaliação de 1.000 exames nas cidades de Barra Mansa e Volta Redonda. RevRadiol Bras. 2010;43(5):295-301.

10. Ministério da Saúde (BR), Instituto Nacional do Câncer. Requisição de mamografia: programa nacional de controle do câncer do colo do útero e da mama [Internet]. Brasilia (DF);2011[citado 2013 set 04]. Available in:http://www. hu.ufsc.br/documentos/doc_01.pdf.

11. Rodrigues DCN, Junior RF, Corrêa RS, Peixoto JE, Tomazelli JG, Rahal RMS. Avaliação do desempenho de diagnóstico na classificação dos laudos mamográficos em rastreamento oportunista do Sistema Único de Saúde (SUS).RevRadiol Bras. 2013;46(3):149-55.

12. Ministério da Saúde (BR), Instituto Nacional do Câncer. Detecção precoce do câncer de mama [Internet]. Brasília (DF); 2013 [citado 2013 set 02]. Available in: http://www.inca.gov.br/conteudo_view.asp?id=1932.
13. Ministério da Saúde (BR), Instituto Nacional do Câncer. Câncer de mama:cuidar da sua saúde é um gesto de amor à vida: fortalecimento da rede de prevenção, diagnóstico e tratamento do câncer. Rio de Janeiro (RJ): Instituto Nacional do Câncer; 2012.

14. Fernandes DA, Silva SMM, Daport AMP, Netto RH, Silva LR, Amorim CSV, Sá FR. Análise da prevalência de exames mamográficos realizados no sistema público de saúde do estado do Acre, Amazônia, Brasil, utilizando-se a classificação Bl-RADS ${ }^{\circledR}$. RevBrasMastologia. 2010;20(2):71-5.

15. Silva PF. Perfil de mulheres com câncer de mama atendidas em Vitória - ES: influência das variáveis sociodemográficas com o estadiamento clínico do tumor antes do tratamento [dissertação]. Vitória (ES): Universidade Federal do Espírito Santo; 2009.

16. Regis-Borges RA, Aburad A, Régis-Aranha LA, Borges EM. Prevalência do câncer de mama em mulheres submetidas a "core biopsy"em Cuiabá-MT. Rev. Uningá. 2013;16(1):39-43.
Author's address:

Samara Ronchi

Rua Operário, 718, Primavera

89980-000, Campo Erê, SC

E-mail: samararonchi@gmail.com
Received: 10.11.2013

Approved: 17.03.2014 